\title{
5S Implementation for Improving the Efficiency Of Manufacturing Service Division in Tangerang
}

\author{
Desy Tri Anggarini \\ ${ }^{1}$ Fakultas Teknologi Informasi, Universitas Bina Sarana Informatika Jakarta . \\ Jl. Kamal Raya No.18, Cengkareng Barat, Cengkareng, Jakarta \\ desy.dra@bsi.ac.id
}

\begin{abstract}
The term of 5 S (Seiri, Seiton, Seiso, Seiketsu and Shitsuke) is the "Point for Kaizen". Seiri is an activity to get rid of or discard items that are not needed and also to sort and group items according to their type and function. Seiton is arranging or placing materials and goods in accordance with the place so that it is easily found again or reached when needed. Seiko is cleaning all facilities and work environment from dirt and throwing trash in its place. Seikuetsu is maintaining personal hygiene, always obeying the three stages (seiri, seiton, seiko). Shitsuke is the attitude to obey the rules, discipline regarding cleanliness, tidiness of the equipment and workplace. $5 \mathrm{~S}$ Implementation Research Methods for Improving the Efficiency of Manufacturing Service Division in Tangerang, using descriptive research here is collecting data based on factors in $5 \mathrm{~S}$ (Seiri, Seiton, Seiso, Seiketsu and Shitsuke) that is to be a supporter of the research object, and then analyze relevant factors.
\end{abstract}

Keywords : Work Culture, Kaizen, Seiri Seiso Seiton Sheiketsu Shitsuke (5S)

\begin{abstract}
Abstrak- P5S (Seiri, Seiton, Seiso, Seiketsu dan Shitsuke) merupakan "Intisari untuk Kaizen". Seiri adalah kegiatan untuk menyingkirkan atau membuang barang-barang yang tidak diperlukan dan juga memilah dan mengelompokan barang-barang sesuai dengan jenis dan fungsinya. Seiton adalah menyusun atau meletakan bahan dan barang sesuai dengan tempatnya agar mudah ditemukan kembali atau dijangkau bila diperlukan. Seiko adalah membersihkan semua fasilitasdan lingkungan kerja dari kotoran serta membuang sampah pada tempatnya. Seikuetsu adalah menjaga kebersihan pribadi, selalu mematuhi ketiga tahapan (seiri, seiton, seiko). Shitsuke adalah sikap untuk mematuhi aturan, disiplin mengenai kebersihan, kerapian terhadap peralatan dan tempat kerja. Metode Penelitian Implementasi 5S Dalam Meningkatkan Efisiensi Divisi Service Perusahaan Manufaktur Di Tangerang, menggunakan penelitian deskriptif disini adalah mengumpulkan data berdasarkan faktor-faktor dalam $5 \mathrm{~S}$ (Seiri, Seiton, Seiso, Seiketsu dan Shitsuke) yaitu menjadi suatu pendukung terhadap objek penelitian, dan kemudian menganalisa faktor-faktor yang relevan.
\end{abstract}

Kata Kunci: Budaya Kerja, Kaizen, Seiri, Seiso, Seiton, Sheiketsu, Shitsuke, 5S

\section{INTRODUCTION}

Globalization and innovation in technology have increased the level of competition especially in the last two decades. To remain in the business arena, every company must reach or exceed customer expectations at the lowest possible price. Improvement and breakthrough innovation has become a necessity to stay in business rather than just a tool to increase company profitability. Therefore, concepts such as Six Sigma, Lean Manufacturing, Continuous Improvements, Quality Circles (QC), Just-in-Time (JIT) have become more popular lately. (Purohit, 2015)[1]

According to N. Nordin et. The ultimate goal of a lean system is to create smooth, high-quality manufacturing that is capable of producing finished products based on customer demand without producing any waste during operations. However, many industries are in fact unable to turn themselves into lean manufacturing organizations to create world-class companies. Because lack of knowledge is one of the most important issues of managers about familiarity with methods that are easy to use to successfully improve organizational performance. Furthermore, in this competitive environment, organizations must make the best judgment and choose the best method to achieve their targets and not lose limited opportunities. This is due to the ineffectiveness of the application of the $5 \mathrm{~S}$ system to the workplace (Noerdin, 2010).[2]

Lean Manufacturing is one method to survive and achieve the success of every organization through minimizing mistakes. The 5S methodology is one of the basic and most important tools for implementing Lean Manufacturing. This is a system for organizing workflows by creating a workplace system, thereby supporting a culture of continuous improvement. (Purohit, 2015).[1] 
$5 \mathrm{~S}$ is a base of Lean Manufacturing systems, the tool for sorting of wanted items from the unwanted items, organizing the required items, regular cleaning of the work place, and providing the necessary groundwork for workplace improvement. $5 \mathrm{~S}$ is a method to get well organized, orderly managed, well cleaned, well standardized and continuously improvi. $5 \mathrm{~S}$, it is one of the efficiently working tools of Lean Manufacturing. The five activities beginning with the letter S, which were derived from five Japanese words. That are Seiri, Seiton, Seiso, Seiketsu and Shitsuke, which translated in English its mean Sort, Set in Order, Shining, Standardize and Sustain, respectively (Salunkhe, 2011)[3]

$5 \mathrm{~S}$ is a systematic methodology used by Industries, organizations and service sectors which is based on five Japanese with a words; Seiri (sort), Seiton (set in order), Seiso (shine), Seiketsu (standardize), and Shitsuke (sustain). This system helps to organize a workplace for efficiency for work and decrease wasting and optimize quality and productivity by monitoring an organized environment. The $5 \mathrm{~S}$ techniques would strongly support the objectives of organization to achieve continuous improvement also as higherperformance (Arash, 2013)[4]

Control of product quality by finding the best way, superior in competition so as to produce quality at every stage of the industry. Quality of the midlle management stage and above requires tools to solve problems with total quality control through a quality control group that is in the unit in every industry. (Tri, 2019).[5]

The company is a collection of management functions from a collection of several people involved in an activity to achieve a goal set by the company. Then the company needs resources to carry out business activities. Resources are needed to manage the company's business activities Human resources have an important role in achieving the stated goals (Siska, 2016).[6]

Lean thinking represents a set of principles also techniques to the identification and elimination of waste in manufacturing, administrative processes. $5 \mathrm{~S}$ is a technique originated from Japan, it was first developed by Hiroyuki Hirano in 1980s. It is five Japanese words Seiri (Sort), Seiton (Set in order), Seiso (Shine), Seiketsu (Standardize) and Shitsuke (Sustain). The 5S philosophy focuses on simplification of the work environment, effective workplace organization, and reduction of waste while improving safety and quality (Patel, 2017)[7]
The implementation of $5 \mathrm{~S}$ and its benefits to various production industries as well as in service sectors. This report represents a literature review to summarize various applications of 5S. The implementation of $5 \mathrm{~S}$ leads to the improvement of the organization in many ways. It will helps the organizations in many ways for the better utilization of working area, improvement in work environment, prevention of tools losing, reduction in accidents, reduction in pollution, discipline among the employee, improved moral of employee, increasing of awareness of employee, improved internal communication, improved internal human relation, decreasing of mistakes through error proofing (Rojasra, 2013)[8]

Manufacturing companies from Japan are engaged in the manufacturing industry of diesel motors, the assembly industry of four / more motorized vehicles and the component industry of four / more motorized vehicles in the service division. The manufacturer has been in Tangerang since 1982 and has implemented a work culture from Japan, namely 5S (Seiri, Seiso, Seiton, Sheiketsu, Shitsuke). Based on the following background, the authors conducted a study entitled 5S Implementation for Improving the Efficiency Of Manufacturing Service Division in Tangerang.

\section{LITERATURE REVIEW}

$5 \mathrm{~S}$ is one of the concepts of innovation originating from Japanese, seiri (sort), seiton (set in order), seiso (shine), seiketsu (standardization) and shitsuke (sustained) . Most companies generally apply the technique to manage the workplace. The application of $5 \mathrm{~S}$ techniques in Japan starts from the manufacturing sector which then extends to the industrial sector and the service sector (Chi, 2011).[9]

Sort (Seiri), is sorting aims for removing all the unwanted materials from the workplace, after sorting the unwanted materials from the workplace, they are placed in the red tag area and the details of it are noted down on the red tag card. The materials noted down on the red tag card are then moved to scrap yard or located properly rectified, segregated or returned to the supplier based on the decision of apex team and zone leader. The necessary and unnecessary materials also available in the workplace should be sorted and classified. Implementation of $5 \mathrm{~S}$ with the visual management will leads to the significance improvement in the work place including the proper 
storage of required items and the efficiently used storage space and the working area. (Patel, 2017)[7]

(Seiton) or Set in Order, its means set in order aims at "place for everything and everything in its place", the specific location is defined for the useful material and located in the predefined order. Tools, equipment, and materials must be systematically arranged for the easiest and the most efficient access. There must be a place for everything, and must be in its place. Forming a regular workplace, avoiding waste of time while searching for material and so improving the efficiency are the main objectives. Improved and properly arranged storage facility leads for the saving of searching time, man/ machine motion, it will contribute in cost saving of the company. The different colors can be used to indicate the different locations \& different areas. There is also all the required items must be properly identified and properly arranged on the fixed location according to its volume and quantity to be stored. (Patel, 2017)[7]

Seiton is straighten, simplify, set in order and configure. The implementation gor easy recognition of each machine, it is mandatory that each and every machine is properly labeled. Sometimes their operating process is also schemed with the machine. The machines are labeled, names and a brief working procedure of machines should be written on the machines for saving valuable time. Choosing a place for hand tools helps workers preserve time also shadow board fulfils this need by containing (Amien, 2019).[10]

(Seiso), there is the meaning of shine aims for keeping cleanliness at workplaces, workstations, offices, stores, outlet, passageways, gangways, etc. in the organization. Cleaning should become a daily activity, the workplace should be cleaned at regular intervals the effective tasks and activities. It is essential to create a clean and regular working and living environment because of dust, dirt and wastes are the source of untidiness, indiscipline, inefficiency, faulty production and work accidents. The regularly cleaned and well-arranged workplace results into improved efficiency of the machines, less scope of human errors, clean and easy to check work place and the healthy accident free of work place, floors washed away and must be cleaned with inspection at regular basis schedule, also storage shelves and storage bins are required to be cleaned. (Patel, 2017)[7]
Seiketsu or Standardize for strictly follow the first $3 S^{\prime}$ in the daily routine, the 4 th $S^{\prime}-$ Standardize is used. Standardize aims for the preparation of standard methods to continue to follow the first $3 \mathrm{~S}^{\prime}$ effectively in the organization, to establish standards of the best practice in place of working and to ensure that the standards are compiled and to undertaking that the workplace is clean and tidy at all times . It is required to choose the best way to practice sort, set in order and shine after there is a need after some period to choose the best ways to practice sort, set in order and cleaning of them. All the activities within the department must be standardize to eliminate the waste and to improve the work place. Formulation of the rules and working standards and its strict establishment is necessary for the improvement in the departmental also organizational operations and work flow. (Patel, 2017)[7]

Shitsuke is sustain aims for maintaining the implemented 5S system effectively, short, sustain defines the discipline for employees to strictly follow the implemented $5 \mathrm{~S}$ in the organization to obtained the required result, also all employees are trained for practicing 5S system. (Patel, 2017)[7]

The term $5 \mathrm{~S}$ is five terms related to workplace maintenance, Seiri, Seiton, Seiso, Seiketsu, Shitsuke. 5S is also known as 5S (Sort, Straighten, Scrub, Systematize, Standardize). Kristianto Jahja stated that $5 \mathrm{~S}$ is the maintenance of the workplace called 5R namely: Ringkas, Rapi, Resik, Rawat, Rajin" (Wiratmani. 2013).[11]

Seiri (Sort) means "Organizing or Election". It means keeping the things that are needed and separating things that are not needed in the job. Stratification management, covering an item and reducing the inventory of goods that are not needed and ensuring that the goods needed are stored in close proximity to be more efficient stratification of classification whether the goods are rarely used will be stored or discarded. The best of management is the ability to make decisions about the frequency of use to ensure that the goods in place. (Wiratmani. 2013).[11]

Seiton (Straighten) is like putting stuff and getting it back easily when needed. After making a concise or the first $R$ of $5 R$, neatly arranged the items needed, namely by grouping items according to 
usage. All items must have a certain name, address and amount. (Wiratmani. 2013).[11]

Seiso (Scrub) the term $5 \mathrm{~S}$ which has the meaning of cleanliness, cleaning means checking. The things done are cleaning machines, working tools, work environment, and various areas in the workplace. Perform cleanliness to ensure environmental conditions, machinery, tools and work facilities are always clean, so they can always be ready for use. (Wiratmani. 2013).[11]

Seiketsu (Systematize) the term 5S means personal order. The concept of personal hygiene continually practices the previous three steps. Standardization in maintaining good conditions. Maintain the neatness of the work environment where employees are faster and safer to obtain the items needed to complete tasks. Color codes are often used in this step to remember where objects. The chaos will arise if an uncomfortable working atmosphere will occur if the settings are not appropriate and are emphasized continuously. This can result an inefficient work atmosphere (Wiratmani, 2013).[11]

Shitsuke (Standardize) is interpreted as a personal discipline. Discipline means applying the abilities of things the way they should, by practicing the previous $4 \mathrm{~S}$ continuously and making it a habit in daily life, by teaching employees what to do and getting them to practice better habits. (Wiratmani. 2013).[11]

Kaizen is optimizing costs and time to produce high quality products. 5S (Seiri, Seiton, Seiso, Seiketsu and Shitsuke). This five-step plan is often also called the five-S (5-S) movement (Herjanto, 2010) : Seiri is an activity to get rid of, throw away items that are not needed, also sort out, classify goods according to the type of function; Seiton is arranging, putting materials, goods in accordance with the place so that it is easily found again, easily accessible if needed.[12]

Seiko is cleaning all facilities and work environment from dirty and throwing trash.

Seikuetsu is maintaining personal hygiene, obeying the three stages above (seiri, seiton, seiko); Shitsuke is an attitude to meet or obey the rules and discipline regarding cleanliness and neatness of equipment and workplaces. Habit of the target to be achieved is an independent attitude (Herjanto,2010).[12]
5S methodology is a system for reducing waste, optimizing productivity by maintaining an orderly workplace by using visual cues to achieve more consistent operational results. $5 \mathrm{~S}$ are the 5 pillars of the visual workplace as mentioned. These are Seiri (Sort), Seiton (Set in sequence), Seiso (Shine), Seiketsu (Standardization) and Shitsuke (Sustain) (Purohit, 2015).[13]

Seiri is needed when the factory becomes very crowded and difficult to work:

lockers, shelves, and cabinets needed for storage so as to speed communication; a lot of time is wasted searching for tools, or parts of work; excess stock covers production problems, the presence of goods; unneeded equipment makes it difficult to increase process flow.

Seiton is needed to help eliminate many types of waste at work:

Motion Waste, people sent to search for vehicles that are looking for a full factory; looking for trash; nobody can find the key to the tool cabinet; human energy waste; frustrated workers give up looking for a place after two hours; excess inventory waste, desk drawers filled with paper and stationery supplies; waste of defective products; goods are not stored back in the same location so workers take the wrong part for assembly; waste conditions are not safe; material boxes are stored on the path, causing someone to trip and get hurt.

Seiso implementation avoids certain problems such as; puddles of oil or water cause slippage and injury; cutting shave, dirt can be mixed in the production resulting in defects; shaving cuts can get into people's eyes and cause injury; the window is very dirty so there is no incoming sunlight; the defects are less obvious in the dark; dirty work environment decreases, good attitude at work.

Seiketsu's implementation avoids such problems : conditions returned to unwanted old levels even after the company's widespread application of $5 \mathrm{~S}$; in the end a pile of unneeded goods was left out of production that day and scattered, tool of storage sites become disorganized and need to be put in order at the end of the day; the shavings are constantly falling to the floor and need to be swept frequently.

Shitsuke's implementation avoids such problems: unnecessary items begin to pile up as soon as the ordering is complete; no matter how well Set in 
Order is planned and implemented, tools and jigs cannot be returned to the specified place after use. No matter how dirty the equipment is, little or nothing is done to clean it.; goods are left protruding into the path, causing people to stumble and get hurt; dirty machines begin to suffer damage and produce defective goods.

\section{METODE RESEARCH METHODS}

The research method in the heading of $5 \mathrm{~S}$ Implementation in Improving the Efficiency of Service Division of Manufacturing Companies in Tangerang, using descriptive research here is collecting data based on factors in $5 \mathrm{~S}$ (Seiri, Seiton, Seiso, Seiketsu and Shitsuke), which are supporting a research object, and then analyze these factors to find their relevant role. (Arikunto, 2010).[14]

Descriptive statistical analysis with a qualitative approach, is an in-depth study of the natural setting or context of an entity as a source of data. Qualitative research is called the naturalistic research method because research is conducted in natural conditions and in accordance with real conditions. (Sugiono, 2012).[15]

Data collection techniques used in research by interview. Esterberg in (Sugiono, 2012) interview is a meeting of two people to exchange information and ideas through questions posed with answers, then produce a communication and form a meaning of a particular topic. The primary data source in this study is the results of interviews.

The 5S implementation research (Seiri, Seiton, Seiso, Seiketsu and Shitsuke), it was carried out with a preliminary study, namely by conducting a survey of the material to be examined in accordance with the title of 5S Implementation in Improving the Efficiency of Manufacturing Service Division Companies in Tangerang, at an early stage done is to collect data through interviews (interviews) and survey list of company data tools. (Siska, 2016)[6]

Research entitled 5S Implementation for Improving the Efficiency Of Manufacturing Service Division in Tangerang. (Putra et al, 2018). [16]

1 . The process of applying the $5 \mathrm{~S}$ (Seiri, Seiton, Seiso, Seiketsu and Shitsuke) to the company, researcher focuses on historical data on the application of the $5 \mathrm{~S}$ culture in the company through interviews.

2. Adaptation of 5S culture (Seiri, Seiton, Seiso, Seiketsu and Shitsuke) to the company. Researchers make adaptations by companies in implementing components.

\section{RESULTS AND DISCUSSION}

\section{Seiri}

Activities to get rid of, throw away unneeded goods, sort and group items according to their type and function. (Herjanto, 2010)[12]. Sorting, differentiating between what is needed and not needed, making decisions firmly and implementing stratification management to get rid of what is not needed. The implementation is cleaning up the whole goods, throwing away everything, that is not needed and handling defective goods, spare parts and products that have been damaged so that the formed stratification management and handle the cause of the problem.

Targets carried out in sorting or Seiri are carried out as needed in the frequency of use of the goods.

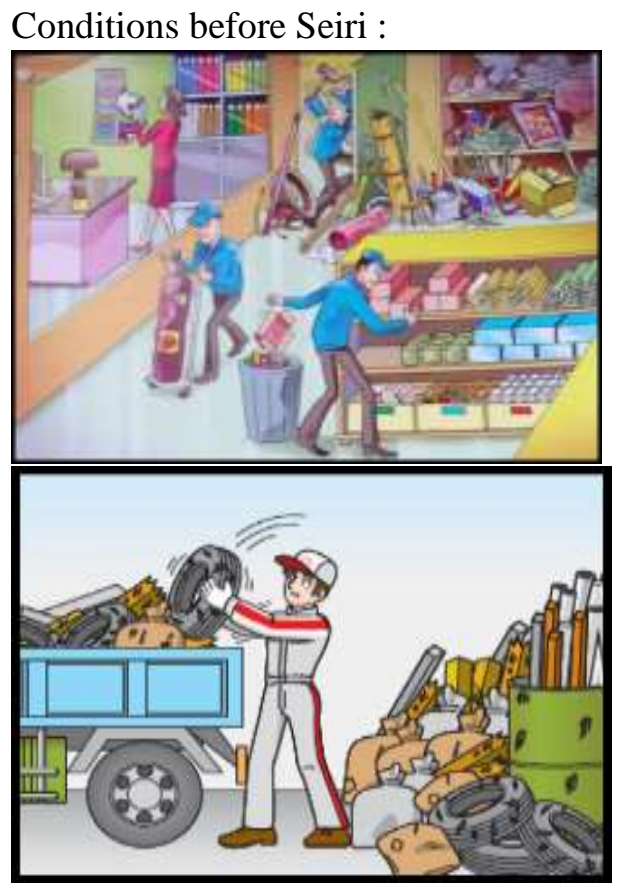

Figure 1.

Before Seiri

Conditions after Seiri 


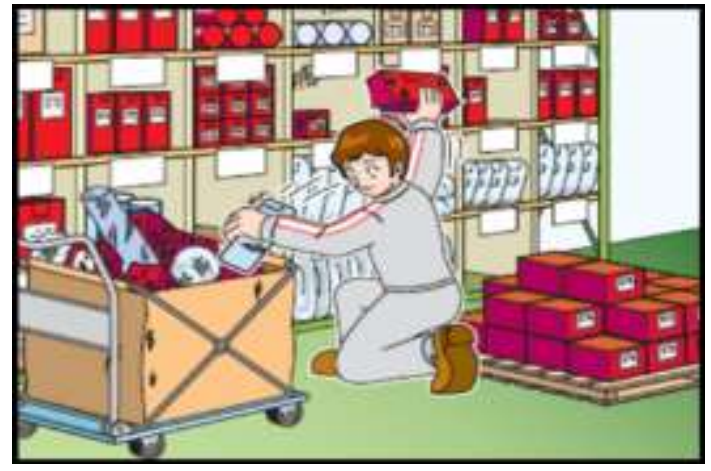

Figure 2.

After Seiri

\section{Seiton}

Seiton is means to arrange, put materials and goods in accordance with the place so that it is easily found again or reached when needed. (Herjanto, 2010)[12]. The principle is to store goods in the right place or in the right layout and label them so that they are easy to find and reach. The implementation is to analyze the goods, then determine the right place, then determine how to store the items and the last for teach everyone to obey the rules of storage.

The principle of arrangement is that goods are stored carelessly which means that the place is not used efficiently and you cannot store as many items as it could be done, as in the following picture irregularly.

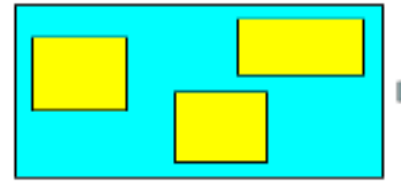

Then the principle of orderly arrangement is that goods are kept perpendicular to each other and along a straight line. The most efficient place to use. The goods face the same direction, as in the following picture:

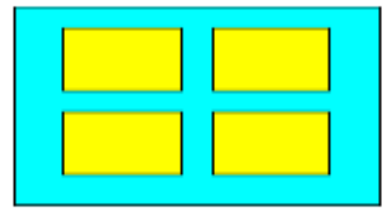

Structuring in the road turn, there is the possibility of collision and damage. Every turn is dangerous. Every turn means slowing the work, as the following picture

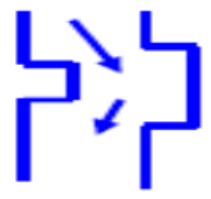

Straight line arrangement is a safe line, so that goods move faster and more efficiently, as the following figure:
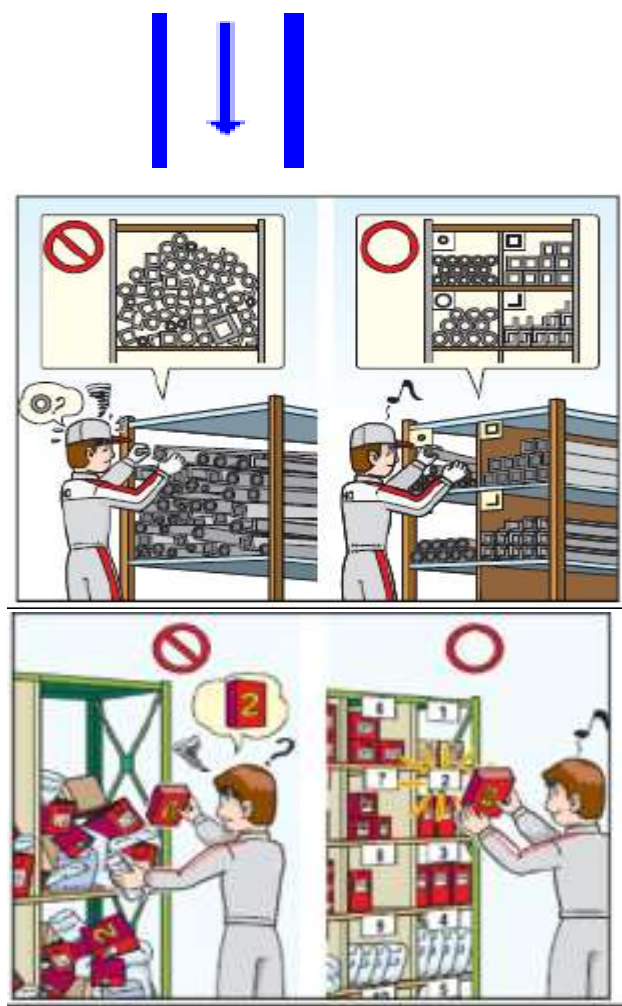

Figure 3.

Implementation before and after Seiton or Structuring

\section{Seiso}

Seiso, it means cleaning all facilities from the work environment from dirt, taking out the trash in its place. (Herjanto, 2010).[12] The principle in Seiso cleaning is a commitment to take responsibility for all aspects of the goods, you use and ensure that all items are in top condition, view cleaning as a form of inspection, remove waste, remove dirt to obtain a cleaner workplace.

Cleaning steps:

1. Micro cleaning everything and handling the overall cause at work

2. Individually by cleaning special workplaces and parts of the workplaces around us. 
3. Micro-cleaning special work equipment, as well as the causes of impurities being identified and repaired.

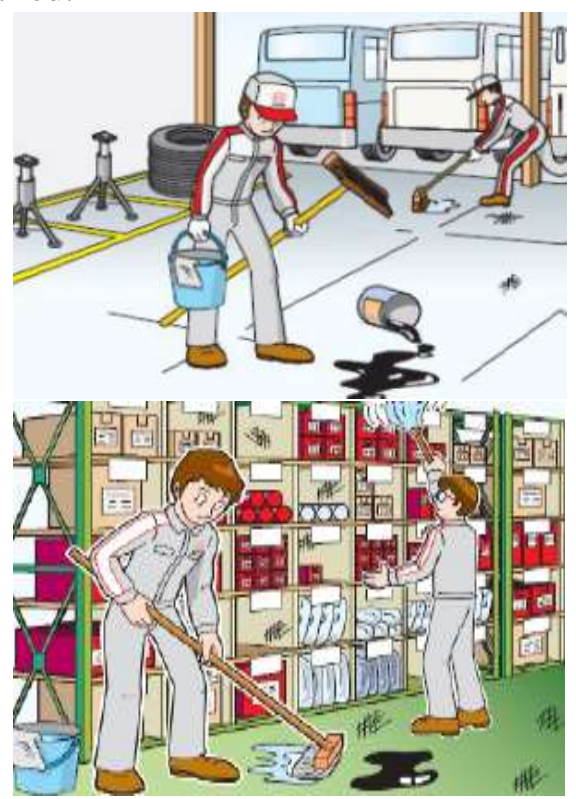

Figure 4.

Implementation of Seiso or Cleanup

\section{Seikuetsu}

Seikuetsu, its means to maintain personal hygiene and always comply with the three stages above (seiri, seiton, seiko). (Herjanto, 2010)[12]. The principal of seiketsu, stabilization, awareness and permanent activities to ensure that $5 \mathrm{~S}$ is maintained, differentiating between normal and non-performing actions or between right and wrong and having clear standards so that everyone can understand. Implementation of stabilization is a demonstration to help people prevent operating errors, be aware of hazards, indications of items to be placed, equipment marking, warnings to be careful in the way of operation, preventive maintenance demonstrations and instructions

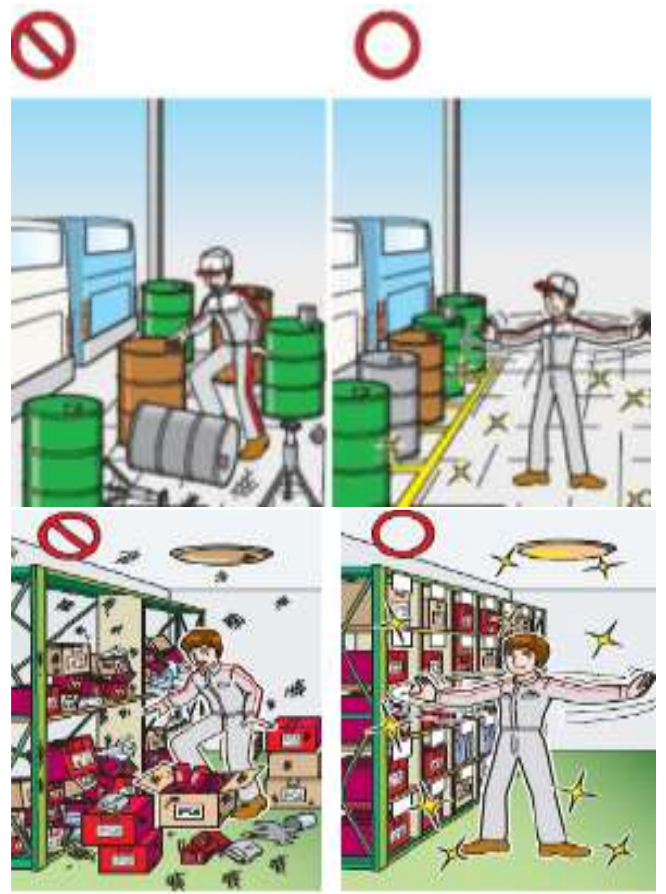

Figure 5.

Implementation of seiketsu or stabilization

\section{Shitsuke}

Shitsuke is forming attitudes to fulfill, obey the rules and discipline regarding cleanliness and neatness of equipment and workplaces. Habit of the target to be achieved is an independent attitude, a system of recognition of the workplace that has successfully implemented 4S successfully (Herjanto, 2010)[12]. The principle of Shitsuke, habituation is to do repetitive work so that it can naturally do it right, change bad habits and create good habits, make rules in which all employees are involved. Every rule that is set must be communicated with every employee, if there are rules that fail to be implemented, it must be discussed again, if there is a discrepancy, efforts must be made to correct it properly and $5 \mathrm{~S}$ will not succeed without habituation. 


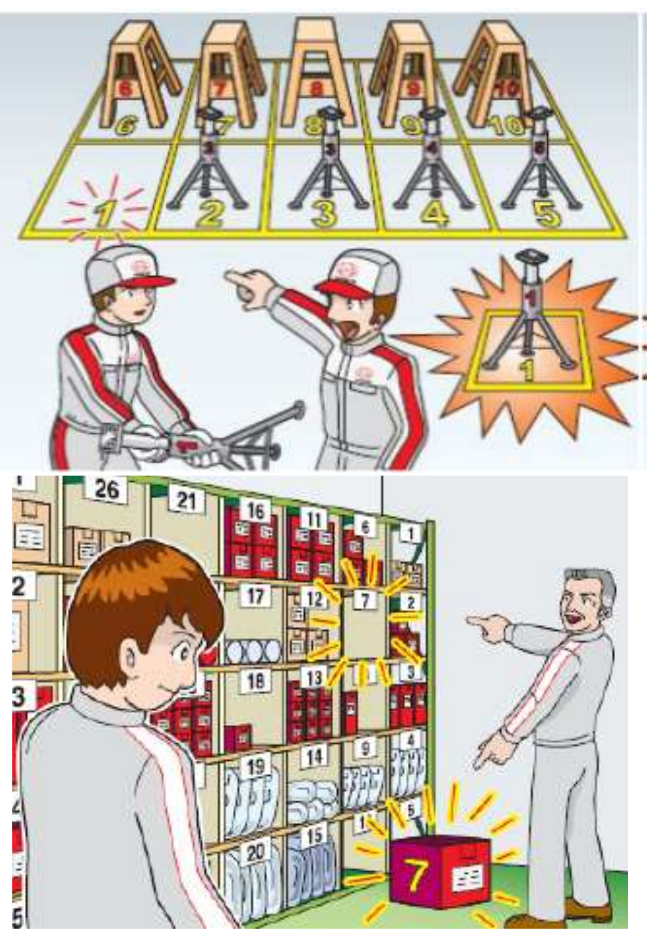

Figure 6.

Implementation of Shitsuke

The implementation of the three-minute activity in the workshop is checking your own clothes, checking for leaks or dropping and picking up any items, rubbish or whatever is available. The implementation of a three-minute activity in administration is checking your own clothes, straightening your tablecloth, checking the location of your desk and file cabinet and rearranging it if it shifts from its place.

The implementation of the five-minute activity in the workshop is wiping the main parts of the machine with a piece of cloth and throwing away everything that is not needed. The implementation of the five-minute activity in administration is to remove unnecessary or personal belongings from your desk drawer, inspect file cabinets, bookshelves and other office furniture and fix them if they are shifted from their places.

The implementation of the ten-minute activity in the workshop is to reattach the loose labels, clean the floor and check the labels, instructions and everything that is wrong. The implementation of the ten-minute activity in administration is to throw away unnecessary things on file cabinets, cabinets, books and other furniture, reattach the labels that are loose and check how many pencils, erasers and other items you have.

\section{CONCLUSION AND SUGGESTION}

The 5S methodology is a system for reducing waste, optimizing productivity through orderly workplace maintenance and using visual cues to achieve more consistent operational results, with $5 \mathrm{~S}$ being the 5 pillars of the visual workplace as mentioned. These are Seiri (Sort), Seiton (Set in sequence), Seiso (Shine), Seiketsu (Standardization) and Shitsuke (Sustain). It is very important to understand why it is necessary to implement each pillar of 5S methodology. (Purohit, 2015)[13].

The application of the Kaizen and $5 \mathrm{~S}$ concepts in this company has run quite well, and the idea of improvement the production itself. The application of Kaizen and 5S, we get the results of reducing waste, in this case reducing waste of space and materials. The implementation of kaizen and $5 \mathrm{~S}$ must be continuously improved and monitored, so that it can continue to develop and will become a culture within the company. The advantages of implementing $5 \mathrm{~S}$ include: reducing process costs and preventing errors, better workplace utility, increasing efficiency and reducing the time to find what is needed, improving safety, improving working conditions and maintaining a clean and neat layout, maintenance costs reduced machinery, increased safety thereby reducing worker injury, reduced product damage due to reduced movement of materials for the process, giving room for worker participation in work area design and maintenance, decreasing the number of absences. (Soesilo, 2017)[17]

Seiri is an activity to get rid of disposing of unneeded goods, sorting, grouping items according to their type and function. The implementation is cleaning up the whole goods, throwing away everything that is not needed and handling defective goods, spare parts and products that have been damaged so that the formed stratification management and handle the cause of the problem.

Seiton means arranging to put materials and goods in accordance with the place so that it is easier to find, reach out when needed. The implementation is to analyze goods, determine the right place, how to store goods and teach everyone to obey the rules in storage.

Seiko is cleaning all work environment facilities from dirt and disposing of garbage, aspects of goods 
used and ensuring that all items are in good condition, cleaning as inspection and removing garbage, dirt, foreign goods so as to make the workplace cleaner.

Seikuetsu is maintaining cleanliness and complying with all three stages (seiri, seiton, seiko). The implementation of stabilization is to help people prevent operating errors, be aware of hazards, indications of where items are placed, equipment marking, caution warnings, ways of operation, preventative maintenance demonstrations and instructions. Shitsuke means the attitude to meet or obey the rules and discipline regarding cleanliness and neatness of equipment and workplaces. Habit of the target to be achieved is the formation of an independent attitude. The principle of shitsuke/ habituation is to do repetitive work so that it can naturally do it right, change bad habits and create good habits, make rules where all employees are involved, each set of rules must be communicated with every employee, if there are rules that fail to be implemented, then must be discussed again, there is a discrepancy, efforts must be made to correct it properly and $5 \mathrm{~S}$ will not succeed without habituation.

Wherever the place where a group of people carry out activities such as at home, workplaces (workshops, offices, hospitals etc.) $5 \mathrm{~S}$ activities can be applied. The difference in each place is only the goods or information encountered. Workshops handle goods or components, and offices handle information or documents. The application of $5 \mathrm{~S}$ can facilitate the work system and is effective in reducing waste, optimizing productivity and maintaining an orderly workplace to achieve optimal and consistent results.

\section{REFERENCES}

[1] S. R. Purohit and V. Shantha, "Implementation-of-5S-Methodology-in-aManufacturing-Industry.doc," vol. 6, no. 8, pp. 225-231, 2015.

[2] and D. W. Nordin, N. B. Deros, "A survey on lean manufacturing implementation in Malaysian automotive industry," Int. J. Innov. Manag. Technol., vol. 1, no, 2010, [Online]. Available: www.ijimt.org. .

[3] P. M. Salunkhe R.T, G.S. Kamble, "Inventory Control and Spare Part Management through 5S, KANBAN and Kaizen at ABC Industry," J. Mech. Civ. Eng., vol. Vol 3/ 39, 2011.

[4] Arash Ghodrati, Norzima Zulkifli, "The Impact of $5 \mathrm{~S}$ Implementation on Industrial Organizations "e Performance," Int. J. Bus. Manag. Invent., vol. $\operatorname{Vol}(2)$, no. 3, [Online]. Available:

https://www.ijbmi.org/papers/Vol(2)3/Version $-1 / \mathrm{G} 234349$. .pdf.

[5] A. Tri Desy, Ani Rakhmanita, "Implementasi Kaizen Dalam Meningkatkan Kinerja Pada Perusahaan Manufaktur Di Tangerang," $J$. Ecodemica, vol. Vol. 3 No., no. 2 September, 2019, [Online]. Available: https://ejournal.bsi.ac.id/ejurnal/index.php/eco demica/article/view/6077.

[6] L. F. S. Siska, Merry, "Analisis Prinsip Kerja 5S dan Motivasi Karyawan di PT. Jasa Barutama Perkasa Pekanbaru Riau," J. Sains, Teknol. dan Ind., vol. Vol. 14, $\mathrm{N}$, no. Desember 2016ISSN 1693-2390 print/ISSN 2407-0939 online, pp. 57-65, 2016, [Online]. Available:

http://ejournal.uinsuska.ac.id/index.php/sitekin /article/view/2710.

[7] Patel Ankit, K. Prashantsingh R, Tomar2 Rajendra P, Nagila, "Reducing Material Searching time by implementing $5 \mathrm{~S}$ in Stores Department of Manufacturing Industry," Int. Conf. Ideas, Impact Innov. Mech. Eng. (ICIIIME 2017), vol. 5, no. ISSN: 2321-8169 Volume: 5 Issue: June 2017., 2017.

[8] M. N. Q. Rojasra P. M., "Performance Improvement through $5 \mathrm{~S}$ in Small Scale Industry: A case study," Int. J. Mod. Eng. Res.

[9] C. H, "5S implementation in Wan Cheng Industry Manufacturing Factory in Taiwan."

[10] A. R. and M. I. S. Amin, Md. Al, Sumit Roy, "Implementation Of 5s In Jute Mill: A Case 
Study Title," J. Eng. Sci. 10(1), 2019, 77-84 Univ. Eng. Technol. Khulna-9203, Bangladesh., vol. 10, no. 1, pp. 77-84, 2019, [Online]. Available: https://www2.kuet.ac.bd/JES/images/files/v10 1/10_JES_208_15-06-2019.pdf.

[11] W. Elfitria, "Analisis Implementasi metode 5S untuk pemeliharaan stasiun kerja proses silk printing di PT Mandom Indonesia Tbk," Factor Exacta Vol 6 No.4., vol. Vol 6 no., 2013, [Online]. Available: https://journal.lppmunindra.ac.id/index.p hp/Faktor_Exacta/article/viewFile/241/227.

[12] E. Herjanto, Manajemen Operasi, 3rd ed. Jakarta: Grasindo: Jakarta, 2010.

[13] V. S. Purohit Soumya R, ), "Implementation of $5 \mathrm{~S}$ Methodology in a Manufacturing Industry, International Journal of Scientific \& Engineering Research," Int. J. Sci. Eng. Res., vol. Purohit So, 2015.

[14] A. S, Prosedur Penelitian:Suatu Pendekatan Praktik., 2010th ed. Jakarta: Rieneka Cipta.

[15] Sugiono., Metode Penelitian Kuatitatif kualitatif dan R\&D. Bandung: Bandung: Alfabeta., 2012.

[16] Putra Novaldi MM., "Analisis Penerapan Budaya Kaizen pada Perusahan Joint Venture ASN Jepang di Indonesia (Studi Pada PT X).
Jurnal Administrasi Bisnis (JAB)," J. Adm. Bisnis, vol. Putra Nova, 2018.

[17] Soesilo Rahman, "Implementasi Kaizen Dan 5S Pada Pengeringan Produk Di Proses Plating," J. Tek. Ind., vol. Vol. 18, N, no. Agustus 2017 ISSN 1978-1431 print / ISSN 2527-4112, pp. 121-126, 2017.

\section{Author's biodata}

Desy Tri Anggarini, SE, MM. Lulusan S1 Fakultas Ilmu Ekonomi Studi Pembangunan Universitas Diponegoro Semarang dan S2 Magister Manajemen Universitas Trisakti Jakarta. Mengajar sebagai dosen di Universitas Bina Sarana Informatika Jakarta. 